\title{
Neonatal Hyperbilirubinemia associated with Minor Blood Group Incompatibility: Two Case Reports
}

\author{
SANJOY KUMER DEY ${ }^{1}$, S AFROZE ${ }^{2}$, ISMAT JAHAN ${ }^{3}$, MA MANNAN $^{4}$, MOHAMMOD SHAHIDULLAH $^{4}$
}

\section{Introduction}

Hyperbilirubinemia is one of the most common neonatal morbidity requiring admission and intervention in majority of the newborns. Haemolytic disease of newborn (HDN) is one of the important cause of hyperbilirubinemia for which evaluation is mandatory. It is defined as incompatibility between maternal and infant blood resulting in the fetal red cell destruction and hyperbilirubinemia in the neonatal period. ${ }^{1} \mathrm{ABO}$ and $\mathrm{Rh}$ incompatibility are the most common cause of clinically significant and serious indirect hyperbilirubinemia. Minor blood group incompatibilities (such as anti-Kell, anti-C, anti-E) are held responsible for $3-5 \%$ of all newborn jaundices. ${ }^{2-4}$ These haemolytic diseases are caused by destruction of fetal and neonatal red blood cells (RBCs) through maternal alloantibody that is specific to paternally inherited red blood cell antigen. ${ }^{5-7}$ The maternal antibody passes through placenta and binds to fetal RBCs. The red blood cell (RBC) destruction process begins from inutero. It presents with a wide variety of severity, from mild anemia, reticulocytosis and neonatal hyperbilirubinemia, to marked fetal anemia and hydropic changes. ${ }^{8}$ Besides $\mathrm{Rh}$ and $\mathrm{ABO}$ isoimmunisation, recently some cases of minor blood group incompatibility are being detected due to advancement of investigation modalities. This study reports two cases of indirect hyperbilirubinemia due to minor blood group incompatibility in newborns of previously transfused mothers, which will help to think about these minor groups.

\section{Hyperbilirubinemia associated with Anti $\mathrm{JK}^{\mathrm{b}}$ antibodies}

A late preterm male newborn of 36 weeks weighing $2600 \mathrm{~g}$ was born to primi 28 year old lady of known case of beta-thalassemia/hemoglobin $(\mathrm{Hb}) \mathrm{E}$, having blood group 'A+ve'. Father was $\mathrm{Hb}-\mathrm{E}$ trait disease.

1. Associate Professor, Department of Neonatology, Bangabandhu Sheikh Mujib Medical University (BSMMU), Dhaka.

2. Specialist, Department of Neonatology, United Hospital Ltd. Gulshan, Dhaka.

3. Medical Officer, Department of Neonatology, Bangabandhu Sheikh Mujib Medical University (BSMMU), Dhaka.

4. Professor, Department of Neonatology, Bangabandhu Sheikh Mujib Medical University (BSMMU), Dhaka.

Correspondence: Dr. Sanjoy Kumer Dey, Department of Neonatology, Bangabandhu Sheikh Mujib Medical University (BSMMU), Dhaka. E-mail: skdey19@gmail.com
Mother required frequent red blood cell transfusions during childhood and three times during the pregnancy. She had $\mathrm{H} / \mathrm{O}$ transfusion reaction two times during this pregnancy. Her Jkb antibody \& both direct and indirect coomb's test during third trimester was found positive. At 36 weeks of gestation, caessarian delivery was done in a tertiary care hospital. At 72 hours of age baby became icteric and got admitted in NICU for further evaluation. There was no signs of bilirubin encephalopathy. Work up regarding hyperbilirubinemia were - blood group 'A+ve', low haemoglobin $(9.8 \mathrm{~g} / \mathrm{dl})$, high reticulocyte count $(>10 \%)$ raised total serum billirubin (14.6mg/dl) \& mild anisochromia in peripheral blood film (PBF), positive Coomb's test. Phototherapy was initiated according to American Academy of Pediatric (AAP) nomogram. Subsequently the baby developed three episodes of rebound hyperbilirubinemia requiring phototherapy. Each episode was associated with significant pallor and jaundice. Repeat investigation findings were low haemoglobin, negative coomb's test and normal reticulocyte count. It was postulated that the cause of anaemia was due to RBC directed antibodies. Two doses of IVIG $(500 \mathrm{mgm} / \mathrm{kg})$ and single shot packed red blood cell were given. Pre-discharge bilirubin and haemoglobin levels were normal. Consequently, the diagnosis of haemolytic disease of newborn due to $\mathrm{JK}^{\mathrm{b}}$ incompatibility was reached as mother was $A$ group with $R^{h}$ positive having anti $J K^{b} A B$, and newborn having $\mathrm{JK}^{\mathrm{b}}$ positive with blood type A positive.

Hyperbilirubinemia associated with anti-C antibodies

Nineteen years old primi mother having blood group B +ve was a diagnosed case of E-beta Thalassemia. She was severely anaemic during her pregnancy period and required multiple packed cell transfusion. She had one episode of transfusion reaction 3 days prior to delivery. At 36 weeks, a female baby weighing $2500 \mathrm{~g}$ was born per vaginally without any complications. She got admitted to NICU at 3 hours of age with significant icterus and pallor. Investigation findings were, mother \& baby's blood groups B+ve, father's blood group A+ve, haemoglobin level $8.2 \mathrm{gm} /$ $\mathrm{dl}$, haemolytic features on peripheral blood film, reticulocyte count $13.4 \%$, total serum bilirubin 11.6 $\mathrm{mg} / \mathrm{dl}$, positive direct and indirect coomb's tests. 
Mother's direct \& indirect Coomb's tests were positive. Baby's G-6PD level was normal (7.2 U/kg). Intensive phototherapy was initiated while arranging blood for exchange transfusion. Double volume exchange transfusion was performed aseptically with 'B+ ve'blood, cross matched with both the mother and the baby at the age of 11 hours. Subsequently the newborn required repeat exchange transfusion due to persisting anaemia and indirect hyperbilirubinemia. Maximum bilirubin was $24.9 \mathrm{mg} / \mathrm{dl}$ and haemoglobin level was between 8-11 g/dl, positive direct \& indirect Coomb's test, reticulocyte count was $3.44 \%$. In view of persistent anaemia and significant hyperbilirubinaemia, the blood was tested for the presence of atypical antibodies. Mother's Rhesus phenotype was CCDee, father's Rhesus phenotype $\mathrm{Cc}^{-}$Dee. Antibody identification from baby \& maternal serum were not done. After $3^{\text {rd }}$ exchange transfusion, four doses inj. Methyl-prednisolone was given (30mg/day) for 3 consecutive days. Subsequent bilirubin levels were below exchange level and baby got phototherapy up to 7 days of life. Baby was improving gradually except pallor after 12 days of life $(\mathrm{Hb}-6.8 \mathrm{~g} / \mathrm{dl})$, got top up transfusion twice. On D-17 baby was discharged with advice for follow up.

\section{Discussion}

The vast majority of cases, Hemolytic disease of newborn (HDN) are due to $\mathrm{ABO}$ sensitization, although most of severe HDN are produced by anti-Rh D. After the use of anti-D immunoglobulin, the incidence of $\mathrm{Rh}(\mathrm{D})$ incompatibility has been decreased. ${ }^{9}$ Hemolytic disease of newborn has become relatively more important to other minor RBC antigens, such as anti$\mathrm{C}$ and anti-E. The proportion of cases that has been caused by Kell, Duffy, kidd and other systems is just around $3 \%$. The antibody of Kidd system responsible for HDN was first reported in 1953(anti $\mathrm{JK}^{\mathrm{b}}$ ) and in 1959 (anti JKa). The JK antibody is clinically significant since it can cause acute and delayed transfusion reaction as well as $\mathrm{HDN}{ }^{10}$

The pathogenesis of maternal sensitisation is through blood transfusion or during pregnancy. Kidd antibodies are of the IgG type that crosses the placenta to cause HDFN. They can bind complements to cause either intravascular or extravascular haemolysis in the infant. ${ }^{11}$ Up to date only 15 cases of HDFN due to anti-Jk $\mathrm{k}^{\mathrm{b}}$ have been reported in the literature worldwide. ${ }^{10,12}$ Clinical presentation of affected newborns ranges from mild anemia and neonatal hyperbilirubinemia to severe fetal anemia and hydrops. ${ }^{13-15}$ After birth, a prolonged period of anemia has been noted, and periodic follow up of infants with maternal alloimmunization is suggested.

The first case was presented with significant jaundice and features of hemolysis requiring phototherapy and blood transfusion. Although antibody elution from newborn RBCs and identification was not done, strongly positive DAT of mother and maternal Jkb antibody may be considered as the cause of anemia in the infant. The second case had severe pallor and underwent three times exchange transfusion due to ongoing progressive indirect hyperbilirubinemia and features of hemolysis.

In summary, RBC alloantibodies to the minor RBC antigen can cause clinically significant hemolysis and it is being found more than previous days. So screening for alloantibodies to minor RBC antigens should be considered in mothers with a history of transfusion. If antibodies are detected, the fetus should be monitored closely for signs of anemia, and postnatally for anemia and indirect hyperbilirubinemia. Also strong clinical suspicion is needed to pick up these cases of persistent neonatal jaundice with indirect hyperbilirubinemia.

\section{References}

1. Chu C F, Cheng PY, Hong C C, Lin M, Ho HT. Hemolytic Disease in Newborn due to maternal antibody of Kidd blood group system at Mackay Memorial Hospital. Blood Bank; Mackay Memorial Hospital, Taiwan.

2. Murki S, Kumar P. Blood exchange transfusion for infants with severe neonatal hyperbilirubinemia. Semin Perinatol. 2011; 35: 175-84.

3. Ip S, Chung M, Kulig J. American Academy of Pediatrics Subcommittee on Hyperbilirubinemia. An evidence-based review of important issues concerning neona-tal hyperbilirubinemia. Pediatrics. 2004;114: e130-53.

4. American Academy of Pediatrics Subcommittee on Hyperbilirubinemia. Management of hyperbilirubinemia in the newborn infant 35 or more weeks of gestation. Pediatrics. 2004;114:297-16.

5. Robitaille N, Nuyt AM, Panagopoulos A, Hume $H A$. Exchange Transfusion in the Infant In: CD Hillyer, RG Strauss, Luban NLC, editors. 
Handbook of pediatric trans-fusion medicine, first ed. Elsevier, Philadelphia 2004: 159-65.

6. Bolat $F$, Uslu $S$, Bülbül $A$, Cömert $S$, Can $E$, Nuhoðlu A. Evalution of term newborns hospitalized in our NICU with the diagnosis of indirect hyperbilirubinemia. Pediatrics J. 2010; 10 (2): 69-74.

7. Özkaya H, Karademir F, Süleymanoðlu S. AntiE antibody related hemolytic disease of newborn: Case re-port. Nobel Med. 2006; 2:24-26.

8. Eder AF. Update on HDFN: new information on longstanding controversies. Immunohematology. 2006;22:188-95.

9. Roberts IA. The changing face of haemolytic disease of the newborn. Early Hum Dev. 2008;84:515-23.

10. Guez D VR, Segura G P, Ubieto AJ, Rodrý'guez M A, Montejano L. Hemolytic Disease of the Newborn Due to Anti-Jkb: Case Report and Review of the Literature. Indian J Hematol Blood Transfus 2014;30:135-38.
11. Thakral B, Malhotra S, Saluja K, Kumar P, Marwaha N. Hemolytic disease of newborn due to anti-Jkb in a woman with high risk pregnancy. Transfusion and Apheresis Science (Elsevierpublished online) 2010

12. Kanner J. Anti-Jkb in erythroblastosis fetalis. Am J Obstet Gynecol. 1962; 83:1253.

13. Babinszki A, Berkowitz RL. Haemolytic disease of the newborn caused by anti-c, anti-E and antiFya antibodies: report of five cases. Prenat Diagn. 1999;19:533-6.

14. Sarici SU, Alpay F, Yesilkaya E, Ozcan O, Gokcay E. Hemolytic disease of the newborn due to isoimmunisation with anti-E antibodies: a case report. Turk J Pediatr 2002;44:248-50.

15. Satake $Y$, Sato Y, Matsumura N, Tatsumi K, Fujiwara H, Konishi I. Middle cerebral artery-peak systolic velocity in dizygotic twins with anti-E alloimmunization. J Obstet Gynaecol Res. 2010;36:1236-39. 